\title{
Market competition, fairness and tax compliance: The formal sector perspective
}

\section{Theresia Woro Damayanti}

Department of Accounting, Universitas Kristen Satya Wacana

Indonesia

theresia.damayanti@uksw.edu

\section{Ade Lisa Matasik}

Department of Accounting, Universitas Kristen Satya Wacana

Indonesia

932017022@student.uksw.edu

\section{Supramono}

Department of Management, Universitas Kristen Satya Wacana

Indonesia

supramono@uk.sw.edu

Abstract. This study aims to investigate the effects of the formal sector's perception of market competition and tax fairness on tax compliance. The data has been borrowed from the World Bank's Survey for the years of 2006-2018 on 49,788 managers of the formal private firms in 140 countries and is analyzed by using the ordered logistic regression. Our results show that the formal sector's perception of market competition and tax fairness affect tax compliance. This study also finds that the interaction between the formal sector's perception of market competition and tax fairness significantly affects compliance. Firms will exhibit greater tax compliance if they consider the competition with the informal sector less intense and tax systems fair. Overall, the results imply that governments need to create conducive market competition and to create and implement fair tax systems.

Keywords: market competition, tax fairness, tax compliance, formal sector.

JEL Classification: H25, H26, L11

\section{INTRODUCTION}

Tax compliance is a challenging issue for developing countries (Kim, Kim, Her \& Kim, 2008; Loo, Evans \& McKerchar, 2010) because of a low level of tax compliance and the complexity of its determinants (Singh \& Bhupalan, 2001). The determinants of tax compliance themselves can be categorized into internal 
and external factors. The internal factors of tax compliance are closely related to firm-specific factors such as firm size (Stamatopoulos, Hadjidema \& Eleftheriou, 2017); firm age, firms' operating areas, and firm location (Stamatopoulos et al., 2017); the legal forms of taxpayers (Stamatopoulos et al., 2017). Besides, taxpayers' tax knowledge (Olaoye, Ayeni-Agbaje \& Alaran-Ajewole, 2017) also empirically affect tax compliance.

Meanwhile, the external factors as the determinants of tax compliance are the countries' corruption level (Alon \& Hageman, 2013; Tahar \& Rachman, 2014; Baum, Gupta, Kimani \& Tapsoba, 2017; Bertinelli, Bourgain \& Leon, 2018; Rosid, Evans \& Tran-Nam, 2018), the service quality of tax officials (Tahar \& Rachman, 2014; Mustapha \& Obid, 2015; Savitri \& Musfialdy, 2016; Jaya, Ratnawati \& Sardjono, 2017), and tax socialization in the form of tax advertisement (Tahar \& Rachman, 2014). Further, the magnitude of tax burden (Blaufus et al., 2015; Gberegbe, Idornigie \& Nkanbia-Davies, 2015); perception on tax information system (Jaya et al., 2017), country’s GDP (Dobrovič, Rajnoha, Voznakova \& Pártlová, 2019) also empirically affect tax compliance.

Another external factor that deserves further analysis is market competition, specifically between the formal sector and the informal one. As suggested by (Gokalp, Lee and Peng, 2017), competition with the informal sector is a factor that constrains formal firms' growth. The informal sector refers to the firms that are not officially registered by authorities but produce legal goods and services (Nichter \& Goldmark, 2009; Bruton, Ireland, \& Ketchen, 2012; Gokalp et al., 2017). Studies conducted in the Latin American, Eastern European, and Central Asian countries demonstrate that the formal sector has to take the presence of informal sector into account (McCann \& Bahl, 2016) because informal firms can rely on their competitive advantages that come from lower innovation and tax costs. The informal sector in the Pacific Alliance countries generates advantages by imitating formal firms' innovating activities and eventually avoiding research \& development costs (Heredia et al., 2017).

Besides, the informal sector often receives favorable tax treatment that helps these firms avoid or reduce tax costs (Benjamin, Beegle, \& Santini, 2014; McCann \& Bahl, 2016). Consequently, the informal sector is better able to set lower product prices than the formal sector (Keen, 2012). When confronted with this situation, a company is faced with three choices. First, do not take any action but the firm thus risks to become uncompetitive. Second, formal firms make cost efficiency efforts intended to reduce prices so they can be more competitive. This effort can be taken, among others, by changing new machines and innovations so that it will increase investment needs that can be met from the results of tax savings (Armstrong et al., 2012, Koster et al., 2016;). Third, formal firms reduce prices which has implications for decreasing profit margins. Therefore, the strategy that can be done by formal companies is to anticipate tax reporting (Karlinger, 2009; Karlinger, 2014) which results in low taxes in an effort to increase net profit.

Although market competition potentially reduces formal firms' tax compliance, Alm, James, Sanchez, and Juan (1995) and Mas'ud, Manaf and Saad (2019) suggest that market competition as an economic factor is insufficient to explain tax compliance behavior because tax involves a psychological contract between taxpayers (formal firms) and governments (Feld \& Frey, 2007). This argument is in line with the fiscal psychology theory that argues that tax compliance is affected not only by economic factors but also by psychological factors (Hasseldine \& Bebbington, 1991) and one of these psychological factors is perceived fairness on legal systems including tax systems (Mei-Tan \& Chin-Fatt, 2000; Kogler et al., 2013).

When taxpayers perceive tax systems as unfair, they arguably perceive their governments to be unfair, partial, and poor, and they are less likely to exhibit tax compliance behavior because of their lower trust to their governments (Yusdita, Subekti, \& Adib, 2017). On the contrary, when taxpayers perceive that tax systems are fair, they are still likely to comply with their tax obligations although they are under intense competition with the informal sector. Thus, tax fairness from governments is an important factor to enhance tax compliance (Murphy, 2007). 
Based on this possibility of interactions between market competition between formal firms and informal firms with perceived fairness on tax compliance, this study aims to test the effects of market competition between formal firms and informal firms and perceived fairness on tax compliance. Previous studies have investigated the effects of competition between formal firms and informal firms on innovation performance (Heredia, Flores, Geldes \& Heredia, 2017); new product development (McCann \& Bahl, 2016); evaluation of the informal sector policies (Williams \& Nadin, 2015); the informal sector's problems (Bruton et al., 2012), executives and their compensation contracts (Karuna, 2007) and the effect of deregulation on competition between the formal and the informal sectors (Karlinger, 2009). However, the literature tends to overlook the role of competition between the formal sector and the informal sector in explaining tax compliance (Mathias, Lux, Crook, Autry \& Zaretzki, 2015). To our best knowledge, only Gokalp et al. (2017) investigated the impact of competition between the formal sector and the informal sector on tax compliance. However, they focused more on the costs and benefits generated by firms for remaining in the formal sector, such as the impacts of higher tax rates (cost) and the ease of banking access (benefit) on tax compliance. Besides, no studies have investigated the effect of the interaction between competition intensity and the perception of tax fairness on tax compliance.

This issue is important because although formal firms are under intense market competition with the informal sector, they are still likely to exhibit greater tax compliance behavior when they have positive perceptions of tax fairness on the side of their governments. Thus, the following are the research questions of this study: (1) Is there a significant effect of market competition between the formal sector and the informal sector on tax compliance; (2) Is there a significant effect of formal firms' perception of tax fairness on tax compliance; and (3) Is there a significant interaction between market competition between the formal sector and the informal sector and the formal sector's perception of tax fairness on tax compliance? This study contributes to the tax compliance literature by providing better understanding of the relationships between competition between the formal sector and the informal sector, perception of tax fairness, and tax compliance.

\section{LITERATURE REVIEW}

\subsection{Theoretical background}

The fiscal psychology theory was initially introduced by Schmolders (1959) that combines the economic and psychological approaches and better explains tax compliance (Hasseldine \& Bebbington, 1991; Feld \& Frey, 2007). Feld and Frey (2002) explain the relationship between taxpayers and tax authorities as an implicit or relational contract involving strong emotional ties that economic factors are insufficient to analyze tax compliance. It is then necessary to explore non-economic factors such as psychological ones to understand tax compliance behavior (James, Murphy \& Reinhart, 2005). Thus, the focus on enhancing tax compliance shifts from the economic approach to the social psychological approach.

The economic approach emphasizes economic rationality by considering the costs and benefits of complying with tax obligations (Hasseldine \& Bebbington, 1991). The economic factors to explain tax compliance include the possibility of being audited (Modugu \& Anyaduba, 2014), tax fines (Poppelwell, Kelly, \& Wang, 2012), the amount of tax burden (Barbuta-Misu, 2011), income level (Kirchler, Muehlbacher, Kastlunger \& Wahl, 2007), the tax amount to be paid (Hyun, 2005), and market competition (Gokalp et al., 2017). Meanwhile, the psychological approach focuses on taxpayers' trust or confidence because of the equal rights and obligations between governments and taxpayers (Hasseldine \& Bebbington, 1991; Feld \& Frey, 2007). The psychological factors include tax morale (Dolores, 2010, Cyan et al., 2016), taxpayers' trust 
(Dijke \& Verboon, 2010, Zemiyanti, 2016, Kostritsad \& Sittler, 2017), and perception on the fairness of tax systems (Murphy, 2007)

\subsection{Hypotheses development}

\subsubsection{The effect of market competition on tax compliance}

Firms are confronted with various competitions in their operations, such as brand competition, industrial competition, form competition, and market competition (Kotler, 2000) and one of the dimensions of competition is market competition (Kubick, Lynch, Mayberry \& Omer, 2015). Many firms are pricesensitive because an important competitive advantage is a low-cost leadership (Porter, 1985). Such competitive advantage aims to control costs tightly and eventually control prices to compete with competitors. Firms that implement this strategy successfully include Wal-Mart (Tanwar, 2013); Southwest Airlines (Heartpreneur, 2017) and Mc. Donalds (Han, 2008).

The formal sector competes not only with other formal firms but also with the informal sector (McCann \& Bahl, 2016). Competing with the informal sector will arguably harm the formal sector in the price competition because of the difference in tax treatments (Benjamin, Beegle, \& Santini, 2014; McCann $\&$ Bahl, 2016). The informal sector is not legally registered and does not have to comply with tax regulations or has lower tax burdens. Consequently, the formal sector's prices are often less competitive than the informal sector's (Keen, 2012).

To overcome market competition, one of the competitive strategies to be adopted by formal firms is to reduce prices. With this strategy, it is expected that formal firms can still compete in the market, but with the consequence of lower profit margins. Low profit margins do not always have implications for low net income if costs can be reduced, one of which is tax costs. Kubicová and Záhumenská (2017) stated that from the viewpoint of corporate finance, taxes are expenses that reduce the after-tax profit. Tax are a significant cost component (Swenson, 1999; Hanlon \& Heitzman, 2010). The high intensity of market competition can encourage companies to tend to conduct unethical behavior such as avoiding taxes and manipulating income (Shleifer, 2004). Meanwhile, Armstrong et al., 2012, Cai and Liu (2009; Koster et al., (2016) explain the motivation to minimize the tax burden is so that companies have more cash to meet investment needs. By investing in new equipment and new machines, formal firms hope to operate at a low cost so they can compete to the informal sector. This especially occurs in companies with unfavorable financial conditions, so they are faced with options to minimize the tax burden in order to maintain existing cash (Khuong, Ha, Minh \& Thu, 2019) which can be used for investment and innovation purposes. The above argument is debatable. Precisely when formal firms face high competition will tend to reduce the firm's intention to make tax avoidance efforts. This is because tax avoidance can have negative effects on firms such as fines, sanctions and tax audits which will further reduce the ability to maintain its competitive position (Kubick, Lynch, Mayberry, \& Omer, 2015). Based on rationality and empirical evidence, we propose the following first hypothesis

$\mathbf{H}_{1}$ : Market competition between the formal sector and informal sector affects tax compliance.

\subsubsection{The effect of tax fairness on tax compliance}

Taxpayers' tendency to comply is closely related to commensurate mutual feeling or fairness between taxes paid to governments and benefits perceived by taxpayers (Mangoting, Sukoharsono, Rosidi \& 
Nurkholis, 2015). Tax fairness covers various dimensions (Saad, 2012). In this respect, Wenzel (2003) explicitly defines tax fairness as an equilibrium perceived by taxpayers on administrative procedures and punishment for violating regulations. Tax fairness can be manifested as distributive fairness, procedural fairness, and retributive fairness (Gberegbe, Idornigie \& Nkanbia-Davies, 2015). Distributive fairness refers to how taxpayers perceive that they are treated equally to other taxpayers in terms of the benefits of tax payments (Kirchler, Kogler \& Muchlbacher, 2014). Meanwhile, procedural fairness is a form of fairness where tax authorities implement tax procedures fairly (Tyler, 2006) and retributive fairness refers to fairness on actions to comply with existing regulations such as audit and sanction.

In the tax compliance literature, taxpayers' perception on (distributive, procedural, and retributive) fairness is an important factor that affects tax compliance behavior (Richardson, 2008; Hartner, Rechberger, Kirchler \& Scabmann, 2008; Palil, Akir, \& Ahmad, 2013; Oberholzer \& Stack, 2014). Taxpayers will arguably increase their compliance when they perceive that the benefits of their tax payments have been provided fairly (Tan \& Chin-Fatt, 2000; Leder, Mannetti, Holzl \& Kirchler, 2010), tax procedures have been implemented fairly (Cropanzano, Rupp, Mohier \& Schminke, 2001; Kim 2002; Chung \& Trevidi, 2003; Tyler 2006; Saad 2014;), and tax audit and sanctions have been implemented fairly (Hofmann, Hoelzl and Kirchler, 2008). However, some previous studies have shown different results, namely, that the perception of tax justice does not affect tax compliance (Coleman 1997; Richardson and Sawyer, 2001). Saad (2012) explains the differences in these results are likely related to differences in systems between countries. The impact of tax fairness on tax compliance is more pronounced in tax systems that adhere to voluntary compliance (Tan \& Chin-Fatt, 2000; Geberegbe et al., 2015). In contrast to the mandatory compliance system where compliance is something that is forced, both taxpayers who feel justice and feel injustice will remain compliant, because they are hit by many sanctions and fines if they are not compliant (Zhiyong \& Qingyang 2007; Saad, 2012). In addition, it is also likely due to differences in community characteristics between developed and developing countries. In developed countries, people will be more individualistic and don't care what other taxpayers do. This can result in no relationship between tax compliance with the perception of tax justice.

Apart from the pros and cons of the results of previous studies, in the context of formal companies, perceptions of tax justice are more likely to affect tax compliance. This is based on the argument that formal firms are more aware of what is happening in their environment. Formal firms will likely continue to try to monitor what their competitors are doing, including tax compliance. In addition, formal firms will also assess whether the government has implemented a fair corporate tax system or not. Fairness perceived by formal firms as taxpayers will create mutual trust and understanding and eventually enhance tax compliance (Hofmann, Hoelzl, \& Kirchler, 2008). In line with this matter, Kogler et al. (2013) also show that perceived fairness of governments' tax systems increases tax compliance. On the contrary, taxpayers who perceive tax systems unfair tend not to comply with tax regulations or not to trust their governments (Damayanti, Nastiti, \& Supramono, 2020; Rudolph, 2009). In a similar vein, the formal sector will increase its tax compliance when the formal sector perceives the fairness of tax systems. Thus, we propose the following hypothesis: $\mathbf{H}_{2}$ : The formal sector's perception of tax fairness affects tax compliance.

\subsubsection{The effect of the interaction between market competition and tax fairness on tax compliance}

The fiscal psychology theory argues that psychological factors complement economic factors in explaining tax compliance. Thus, market competition as an economic factor is insufficient to illuminate tax compliance. Market competition is not alone in influencing the formal sector's tax compliance because it is 
likely that it interacts with the fairness of tax systems as a psychological factor in increasing or decreasing its effect on tax compliance.

Taxpayers will exhibit greater tax compliance when they consider tax systems fair (Palil, Akir, \& Ahmad, 2013) although they are under intense competition with the informal sector. On the contrary, taxpayers who have a low perception of tax fairness and experience less intense market competition are likely to exhibit tax compliance behavior because they consider their position as formal taxpayers still beneficial. The pronounced benefits as formal taxpayers motivate them to comply with tax regulations (Barbuta-Misu, 2011). Formal taxpayers who are under intense competition with the informal sector but experience tax fairness will generate psychological benefits while formal taxpayers who are under less intense competition with the informal sector but do not experience tax fairness will generate economic benefits. Furthermore, when taxpayers experience both less intense market competition, and greater tax fairness will generate both economic and psychological benefits that they will exhibit much greater tax compliance behavior (Hasseldine \& Bebbington, 1991).

In line with the fiscal psychology theory, the optimal tax compliance behavior will hold when both the economic and psychological factors confirm taxpayers' expectations (Hasseldine \& Bebbington, 1991; Feld \& Frey, 2007). In this respect, the formal sector will arguably exhibit greater tax compliance when it experiences lower market competition with the informal sector and greater tax fairness. Thus, we propose the following hypothesis:

$\mathbf{H}_{3}$ : The interaction between market competition and the formal sector's perception of tax fairness affects tax compliance.

\section{METHODOLOGY}

We use the data from the World Bank's Survey for the years of 2006-2018. This survey asked 13 factors, namely regulations and taxes, corruption, crime, informality, gender, finance, infrastructure, innovation and technology, trade, workforce, firm characteristics, the biggest obstacle and performance. Overall, the survey was administered in 140 countries with 117,357 formal and informal business owners as the respondents. However, this study only uses legal firms as the sample because this study uses the tax compliance framework. Consequently, the final sample is 49,788 respondents of legal firms.

This study uses tax compliance as the dependent variable and perceived market competition and perceived tax fairness as the independent variables. In this respect, we use tax inspection as the indicator of tax compliance level. Tax inspection is the indicator of tax compliance because firms that are frequently audited by tax authorities indicate that these firms have tax compliance problems (OECD, 2014). Next, we measure perceived market competition by using the degree of competition with the informal sector experienced by formal firms. The informal sector refers to firms that are not legally registered with government authorities but produce legal goods and services (Nichter \& Goldmark, 2009; Bruton et al., 2012; Gokalp et al., 2017). Further, we measure perceived tax fairness by the extent firms perceive the legal system, in this respect tax law, is fair, neutral, and clean.

Firms' decision to comply is affected by various factors. Consequently, this study includes several control variables into its analysis, namely firm size, perceived tax burden, firm age, and family firm. Firm size has a significant impact on tax compliance; larger firms are more compliant than smaller ones (Sapiei, Kasipillai, \& Eze, 2014). We use the number of employees as the proxy of firm size. Specifically, firms with 5-19 employees are classified as small firms, firms with 20-99 employees are classified as medium firms, and finally, firms with more than 100 employees are classified as large firms. Next, we measure perceived tax burden with an indicator questioning how taxpayers perceive the fairness of their tax burden. Previous studies inform a significant relationship between perceived fairness of tax burden and tax compliance 
(Gberegbe et al., 2015). More specifically, taxpayers prefer progressive tax rates due to fairness reason (Blaufus et al., 2015). Further, we measure firm age by subtracting the year 2018 with the firm's foundation year. Older firms exhibit greater tax compliance (Sapiei et al., 2014). Meanwhile, family firms tend to engage more in tax evasion (Chen et al., 2010). We use the proportion of family ownership as the proxy of family firm. A firm with family ownership greater (less) than $50 \%$ is classified as a (non-) family firm.

We use the ordered logistic regression (OLR) to test hypotheses 1 and 2 in our overall sample. OLR is a regression model used to test the effect of independent variables on the dependent variable, where the dependent variable is a variable with an ordinal scale. In this study, the dependent variable, namely tax compliance, is measured using three categories, namely full compliance, partially compliance and no compliance, therefore it is appropriate to use OLR as an analysis tool. The following is our OLR specification:

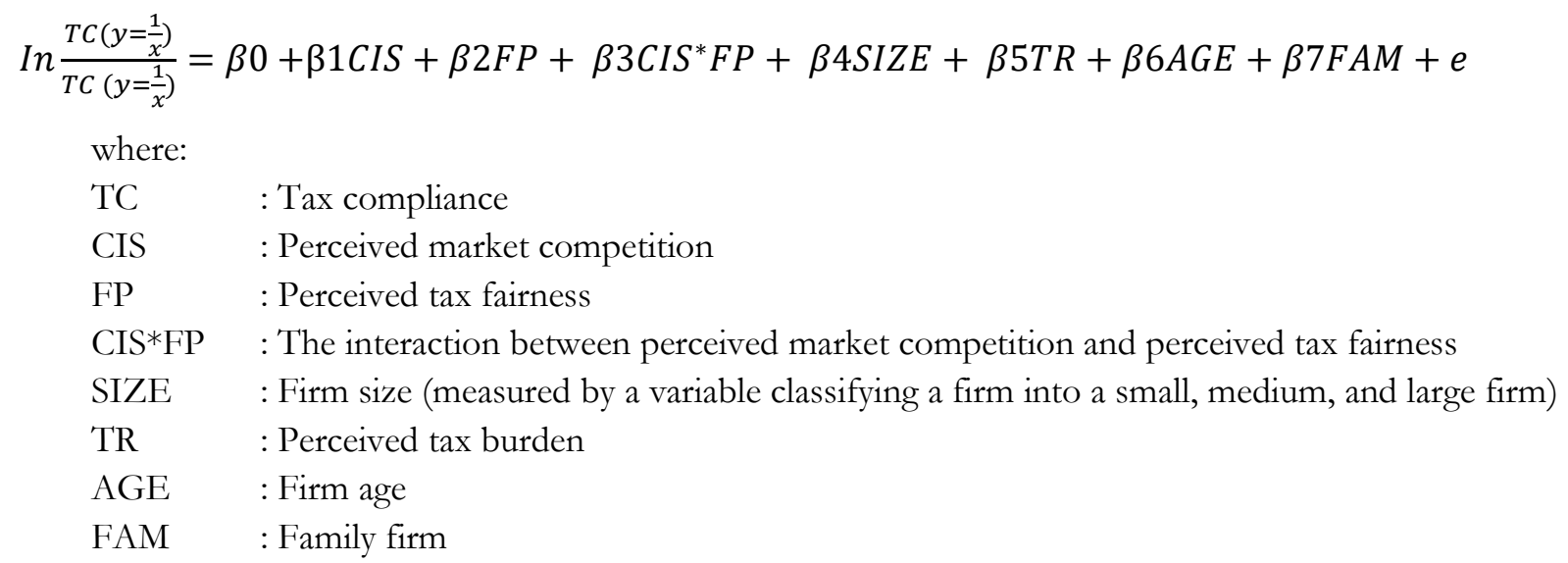

OLR does not require some classical assumption tests, namely normality test, heteroscedasticity test, multicollinearity test, autocorrelation test, linearity test, univariate and multivariate outlier tests such as linear regression using parametric data. For the robustness test, this study also uses linear regression to test hypothesis 1 and hypothesis 2 . In the robustness test, the tax compliance variable is no longer measured using a nominal scale but by using a ratio scale, namely the number of times the taxpayer is subject to tax audits.

To test hypothesis 3, we split our respondents into two subsamples (high vs. low market competition; high vs. low perceived tax fairness). The categorization of the independent variables is carried out to see differences in tax compliance between categories.

\section{EMPIRICAL RESULTS AND DISCUSSION}

The descriptive statistics of 49,788 formal firms in 140 countries demonstrate that most respondents $(32.85 \%)$ do not experience high competition with the informal sector with the mean value of the responses of 1.53. For the perceived tax fairness variable, most respondents perceive tax systems fair (32.07\%), and the mean value of respondents' perception of tax fairness is 2.3. Lastly, for the tax compliance variable, most respondents are partially compliant (the average value of 1.99 ). 
Table 1

Descriptive statistics

\begin{tabular}{|c|c|c|c|c|}
\hline \multicolumn{2}{|c|}{ Variable } & $\%$ & Mean & Std. \\
\hline Perceived Market Competition & $\begin{array}{l}\text { Very High } \\
\text { High } \\
\text { Moderate } \\
\text { Low } \\
\text { Very Low }\end{array}$ & $\begin{array}{l}10.43 \\
17.14 \\
20.47 \\
19.11 \\
32.85\end{array}$ & 1.53 & 1.369 \\
\hline Perceived Tax Fairness & $\begin{array}{l}\text { Very Fair } \\
\text { Fair } \\
\text { Unfair } \\
\text { Very Unfair }\end{array}$ & $\begin{array}{l}12.37 \\
32.07 \\
28.91 \\
26.65\end{array}$ & 2.30 & 0.996 \\
\hline Tax Compliance & $\begin{array}{l}\text { Full Compliance } \\
\text { Partial Compliance } \\
\text { No Compliance }\end{array}$ & $\begin{array}{c}0.03 \\
99.02 \\
0.95\end{array}$ & 1.99 & 0.099 \\
\hline
\end{tabular}

Source: Authors' results.

Table 2 shows the relationship between variables and suggests that most respondents who consider market competition high opt for no compliance (19.58\% and 14.32\%). On the contrary, formal firms who perceive market competition low exhibit full compliance $(35.72 \%$ and $42.68 \%)$. With respect to the relationship between the perceived tax fairness variable and the tax compliance variable, our findings indicate that respondents who experience tax fairness exhibit full compliance $(42.86 \%$ and $28.57 \%$ and those who do not experience tax fairness opt for no compliance $(29.05 \%$ and $34.53 \%)$.

Table 2

Relationship with tax compliance

\begin{tabular}{|c|c|c|c|c|}
\hline & $\begin{array}{l}\text { Full Compliance } \\
(n=14)\end{array}$ & $\begin{array}{c}\text { Partial Compliance } \\
(\mathrm{n}=49.299)\end{array}$ & $\begin{array}{c}\text { No Compliance } \\
(\mathrm{n}=475)\end{array}$ & Total \\
\hline \multirow{2}{*}{$\begin{array}{l}\text { Perceived Market Competition } \\
\text { Very High }\end{array}$} & & & & \\
\hline & $\begin{array}{c}1 \\
(7.14 \%)\end{array}$ & $\begin{array}{c}5,125 \\
\left(10.40^{\circ} \%\right)\end{array}$ & $\begin{array}{c}68 \\
(14.32 \%)\end{array}$ & $\begin{array}{c}5,194 \\
(10.4 \%)\end{array}$ \\
\hline High & $\begin{array}{c}1 \\
(7.14 \%)\end{array}$ & $\begin{array}{c}8,438 \\
(17.11 \%)\end{array}$ & $\begin{array}{c}93 \\
(19.58 \%)\end{array}$ & $\begin{array}{c}8,532 \\
(17.1 \%)\end{array}$ \\
\hline Moderate & $\begin{array}{c}1 \\
(7.14 \%)\end{array}$ & $\begin{array}{c}10,101 \\
(20.49 \%)\end{array}$ & $\begin{array}{c}92 \\
(19.37 \%)\end{array}$ & $\begin{array}{c}10,194 \\
(20.5 \%)\end{array}$ \\
\hline Low & $\begin{array}{c}5 \\
(35.72 \%)\end{array}$ & $\begin{array}{c}9,421 \\
(19.11 \%)\end{array}$ & $\begin{array}{c}86 \\
(18.10 \%)\end{array}$ & $\begin{array}{c}9,512 \\
(19.1 \%)\end{array}$ \\
\hline Very Low & $(42.86 \%)$ & $\begin{array}{c}16,214 \\
(32.89 \%)\end{array}$ & $\begin{array}{c}136 \\
(28.63 \%)\end{array}$ & $\begin{array}{l}16,356 \\
(32.9 \%)\end{array}$ \\
\hline \multicolumn{5}{|l|}{ Perceived Tax Fairness } \\
\hline Very Fair & $\begin{array}{c}4 \\
(28.57 \%)\end{array}$ & $\begin{array}{c}6,105 \\
(12.83)\end{array}$ & $\begin{array}{c}50 \\
(10.53)\end{array}$ & $\begin{array}{c}6,159 \\
(12.4 \%)\end{array}$ \\
\hline Fair & $\begin{array}{c}6 \\
(42.86 \%)\end{array}$ & $\begin{array}{c}15,839 \\
(32.13 \%)\end{array}$ & $\begin{array}{c}123 \\
(25.89 \%)\end{array}$ & $\begin{array}{c}15,968 \\
(32.1 \%)\end{array}$ \\
\hline Unfair & $\begin{array}{c}1 \\
(7.14 \%)\end{array}$ & $\begin{array}{c}14,254 \\
(28.91 \%)\end{array}$ & $\begin{array}{c}138 \\
(29.05 \%)\end{array}$ & $\begin{array}{c}14,393 \\
(28.9 \%)\end{array}$ \\
\hline Very Unfair & $\begin{array}{c}3 \\
(21.43 \%)\end{array}$ & $\begin{array}{c}13,101 \\
(26.57 \%)\end{array}$ & $\begin{array}{c}164 \\
(34.53 \%)\end{array}$ & $\begin{array}{l}13,268 \\
(26.6 \%)\end{array}$ \\
\hline
\end{tabular}

Source: Authors' results. Full compliance $=$ the firm was never inspected over the last year; Partial compliance $=$ the firm was inspected by tax officials for less than 30 days over the last year, and no compliance $=$ the firm was inspected by tax officials for at least 30 days over the last year. 
Based on the Spearman correlation table, the variable of perceived market competition between the formal sector and informal sector and the variable of perceived tax fairness are weakly correlated (coefficient $>0-0.25)$ but significantly $($ sig $<0.01)$ with tax compliance. This means that there is a relationship between the independent variables that is perceived market competition between the formal sector and the informal sector with the perceived tax fairness. When taxpayers feel that there is a high market competition between the formal sector and the informal sector, the taxpayer feels tax unfair as a result of competition between the formal and informal sectors.

As the control variables, firm age and firm size are also significantly correlated with tax compliance, which means that the characteristics of the company that is a control variable in this study has associated with tax compliance. However, perceived tax burden and family firm do not correlate significantly. Table 3 also informs that there is no serious multicollinearity problem because there is no high correlation coefficient. Thus, all variables are usable in the analysis by using the multinomial logit analysis.

Table 3

Spearman correlation

\begin{tabular}{|l|l|l|l|l|l|l|l|}
\hline & \multicolumn{1}{|c|}{$(1)$} & \multicolumn{1}{|c|}{$(2)$} & $(3)$ & $(4)$ & $(5)$ & $(6)$ & $(7)$ \\
\hline Tax Compliance (1) & 1.000 & & & & & & \\
\hline Perceived Market Competition & -0.014 & 1.000 & & & & & \\
(2) & $0.001^{* * *}$ & & & & & & \\
\hline Perceived Tax Fairness (3) & 0.019 & -0.133 & 1.000 & & & & \\
& $0.000^{* * *}$ & $0.000^{* * *}$ & & & & & \\
\hline Firm Size (4) & -0.027 & -0.084 & 0.023 & 1.000 & & & \\
& $0.000^{* * *}$ & $0.000^{* * *}$ & $0.000^{* * *}$ & & & & \\
\hline Firm Age (5) & -0.019 & 0.060 & -0.050 & 0.259 & 1.000 & & \\
& $0.000^{* * *}$ & $0.000^{* * *}$ & $0.000^{* * *}$ & $0.000^{* * *}$ & & & \\
\hline Perceived Tax Burden (6) & 0.000 & -0.001 & -0.004 & 0.001 & -0.002 & 1.000 & \\
& 0.929 & 0.839 & 0.399 & 0.770 & 0.580 & & \\
\hline Family firm (7) & 0.004 & 0.005 & 0.006 & -0.161 & 0.122 & 0.002 & 1.000 \\
& 0.398 & 0.244 & 0.161 & $0.000^{* * *}$ & $0.000^{* * *}$ & 0.710 & \\
\hline
\end{tabular}

Source: Authors' results. * indicates significance level at 0.10 level, ** indicates significance level at 0.05 level, *** indicates significance level at 0.01 level

As shown in Table 4, the logistic multinomial regression estimation results in the pseudo $\mathrm{R}^{2}$ value of 0.017 ( $\mathrm{p}$-value 0.000 ), suggesting that the independent variables significantly predict the dependent variable. Next, Panel A of Table 4 demonstrates that perceived market competition between the formal sector and informal sector significantly affects tax compliance ( $\mathrm{p}$-value 0.091), thus supporting $\mathrm{H}_{1}$. Similarly, $\mathrm{H}_{2}$ is empirically supported ( $\mathrm{p}$-value 0.003), implying that perceived tax fairness significantly affects tax compliance.

The firm size and firm age variables also significantly affect tax compliance. However, perceived tax burden and family firm do not significantly affect tax compliance.

As can be seen at Panel B of Table 4, we run the linear regression to ensure the robustness of our findings. In this test, we measure tax compliance with a ratio scale and not with a nominal scale as our multinomial regression test. Our alternative test confirms previous results that show the effects of market competition and perceived tax fairness on tax compliance. 
Test of hypotheses

\begin{tabular}{|c|c|c|c|}
\hline \multicolumn{4}{|c|}{ Panel A. The Ordered Logistic Regression Test } \\
\hline Variable & $\chi^{2}$ & p-value & Explanation \\
\hline Perceived Market Competition & $3,127.438$ & $0.091 *$ & $\mathrm{H}_{1}$ supported \\
\hline Perceived Tax Fairness & $3,121.525$ & $0.003 * * *$ & $\mathrm{H}_{2}$ supported \\
\hline \multicolumn{4}{|l|}{ Control Variable } \\
\hline Firm Size & $3,137.599$ & $0.000 * * *$ & \\
\hline Firm Age & $3,119.071$ & $0.004 * * *$ & \\
\hline Perceived Tax Burden & $3,017.864$ & 0.999 & \\
\hline Family firm & $3,108.625$ & 0.683 & \\
\hline \multicolumn{4}{|c|}{$\begin{array}{l}\text { Number of observations }=49,788 ; \text { Wald } \chi^{2}=3.107,863 ; \text { probability } \chi^{2}=0.000 ; \text { Pseudo } \mathrm{R}^{2}=0.017 \text {; } \\
\qquad{ }^{*}<0,1 ;{ }^{* *} p<0,05 ; *^{* * *}<0,01\end{array}$} \\
\hline \multicolumn{4}{|c|}{ Panel B. The Linear Regression Test } \\
\hline Variable & $B$ & $\operatorname{sig}$ & \\
\hline Perceived Market Competition & -0.14 & $0.002 * * *$ & $\mathrm{H}_{1}$ supported \\
\hline Perceived Tax Fairness & 0.017 & $0.000 * * *$ & $\mathrm{H}_{2}$ supported \\
\hline \multicolumn{4}{|l|}{ Control Variable } \\
\hline Firm Size & -0.025 & $0.000^{* * *}$ & \\
\hline Firm Age & -0.018 & $0.000^{* * *}$ & \\
\hline Perceived Tax Burden & 0.000 & 0.969 & \\
\hline Family firm & -0.003 & 0.561 & \\
\hline \multicolumn{3}{|c|}{$*_{\text {sig }}<0.1 ; *^{*}$ sig $<0.05 ; * * *_{\text {sig }}<0.01$} & \\
\hline
\end{tabular}

Source: Authors' results. * indicates significance level at 0.10 level, ** indicates significance level at 0.05 level, *** indicates significance level at 0.01 level

Table 5 demonstrates our testing of $\mathrm{H}_{3}$ that predicts the effect of the interaction between perceived market competition between the formal sector and informal sector and perceived tax fairness on tax compliance. Panel A of Table 5 indicates the significant difference (sig.0.012) of the four interaction types of perceived market competition between the formal sector and informal sector and perceived tax fairness. The highest average tax compliance (6.49) is shown by the condition of low perceived market competition between the formal sector and informal sector and high perceived tax fairness. On the contrary, the lowest average tax compliance (5.65) is indicated by the condition of high perceived market competition between the formal sector and informal sector and low perceived tax fairness. Thus, the findings suggest that $\mathrm{H}_{3}$ is empirically supported.

We also analyze the effect of the interaction between perceived market competition between the formal sector and informal sector and perceived tax fairness on tax compliance by running the regression test in four models (Panel B of Table 5). Model 1 is a regression test on respondents with low perceived market competition between the formal sector and informal sector; model 2 analyzes respondents with high perceived market competition between the formal sector and informal sector, model 3 applies for respondents with high perceived tax fairness and model 4 tests respondents with low perceived tax fairness. Our test in model 1 shows that when perceived market competition between the formal sector and informal sector is low, perceived tax fairness significantly affects tax compliance (sig 0,000). In model 2, when perceived market competition between the formal sector and informal sector is high, perceived tax fairness does not affect tax compliance (sig 0,170). Next, when perceived tax fairness is high (model 3), perceived market competition between the formal sector and informal sector significantly affects tax compliance (sig 0,006). Lastly, when perceived tax fairness is low (model 4), perceived market competition between the formal sector and informal sector does not affect tax compliance (sig 0,166). Thus, formal firms exhibit the 
greatest tax compliance behavior when they consider market competition with informal firms low and tax fairness high.

Table 5

The interaction analysis

\begin{tabular}{|c|c|c|c|}
\hline \multicolumn{4}{|c|}{ Panel A. Univariate Regression Test } \\
\hline \multicolumn{2}{|c|}{ Interaction } & Average Compliance Level & Sig \\
\hline \multicolumn{2}{|c|}{ Low Competition-High Fairness } & 6.49 & \multirow[t]{4}{*}{$0.012^{* *}$} \\
\hline \multicolumn{2}{|c|}{ Low Competition- Low Fairness } & 6.21 & \\
\hline \multicolumn{2}{|c|}{ High Competition - High Fairness } & 6.32 & \\
\hline \multicolumn{2}{|c|}{ High Competition - Low Fairness } & 5.65 & \\
\hline \multicolumn{4}{|c|}{ Panel B. Linear Regression Test } \\
\hline Model & V ariabel Independen & $\beta$ & Sig \\
\hline \multirow[t]{2}{*}{$\begin{array}{l}\text { Model 1. Low Perceived } \\
\text { Market Competition }\end{array}$} & $\begin{array}{l}\text { Perceived Market } \\
\text { Competition }\end{array}$ & -0.003 & 0.567 \\
\hline & Perceived Fairness & 0.019 & $0.000^{* * *}$ \\
\hline \multirow[t]{2}{*}{$\begin{array}{l}\text { Model 2. High Perceived } \\
\text { Market Competition }\end{array}$} & $\begin{array}{l}\text { Perceived Market } \\
\text { Competition }\end{array}$ & -0.009 & 0.304 \\
\hline & Perceived Fairness & 0.012 & 0.170 \\
\hline \multirow[t]{2}{*}{$\begin{array}{l}\text { Model 3. High Perceived } \\
\text { Fairness }\end{array}$} & $\begin{array}{l}\text { Perceived Market } \\
\text { Competition }\end{array}$ & -0.018 & $0.006^{* * *}$ \\
\hline & Perceived Fairness & -0.01 & 0.900 \\
\hline \multirow[t]{2}{*}{$\begin{array}{l}\text { Model 4. Low Perceived } \\
\text { Fairness }\end{array}$} & $\begin{array}{l}\text { Perceived Market } \\
\text { Competition }\end{array}$ & -0.008 & 0.166 \\
\hline & Perceived Fairness & -0.012 & $0.053^{*}$ \\
\hline
\end{tabular}

Source: Authors' results. * indicates significance level at 0.10 level, ** indicates significance level at 0.05 level, *** indicates significance level at 0.01 level

Another additional test analyzes the differences in compliance for each interaction as demonstrated by Table 6. The table informs that interaction 1 (high perceived market competition and low perceived tax fairness), and interaction 4 (low perceived market competition and high perceived tax fairness) are significantly different. Besides, the results also suggest that there are no significant differences between other interactions. Overall, the findings imply that the condition that affects tax compliance most significantly is the interaction between low (high) perceived market competition and high (low) perceived tax fairness.

Table 6

The results of difference tests of tax compliance between interactions

\begin{tabular}{|l|l|c|c|}
\hline \multicolumn{2}{|l|}{ Interaction } & Coefficient & Sig \\
\hline \multirow{4}{*}{$\begin{array}{l}\text { 1. High Competition-Low } \\
\text { Fairness }\end{array}$} & High Competition - High Fairness & 0.66 & 0.216 \\
\cline { 2 - 4 } & Low Competition - Low Fairness & 0.56 & 0.119 \\
\cline { 2 - 4 } & Low Competition - High Fairness & 0.84 & $0.006^{* * *}$ \\
\hline \multirow{2}{*}{$\begin{array}{c}\text { 2. High Competition-Low } \\
\text { Fairness }\end{array}$} & High Competition - High Fairness & -0.66 & 0.216 \\
\cline { 2 - 4 } & Low Competition - Low Fairness & -0.11 & 0.985 \\
\cline { 2 - 4 } & Low Competition - High Fairness & 0.17 & 0.944 \\
\hline \multirow{3}{*}{$\begin{array}{c}\text { 3. Low Competition-Low } \\
\text { Fairness }\end{array}$} & High Competition - Low Fairness & -0.56 & 0.119 \\
\cline { 2 - 4 } & High Competition - High Fairness & 0.11 & 0.985 \\
\cline { 2 - 4 } & Low Competition - High Fairness & 0.28 & 0.510 \\
\hline \multirow{3}{*}{$\begin{array}{c}\text { 4. Low Competition-High } \\
\text { Fairness }\end{array}$} & High Competition - Low Fairness & -0.84 & $0.006^{* * *}$ \\
\cline { 2 - 4 } & High Competition - High Fairness & -0.17 & 0.944 \\
\cline { 2 - 4 } & Low Competition - Low Fairness & -0.28 & 0.510 \\
\hline
\end{tabular}

Source: Authors' results. $*$ indicates significance level at 0.10 level, $* *$ indicates significance level at 0.05 level, $* * *$ indicates significance level at 0.01 level 
Our findings demonstrate that market competition between the formal sector and informal sector empirically affects tax compliance. A high level of perceived market competition between the formal sector and informal sector tends to motivate the formal sector to avoid taxes to remain competitive. The results are in line with Keen (2012); Benjamin et al. (2014); and McCann \& Bahl (2016). Tax avoidance carried out by formal companies when perceived high level of competition with informal sector through two arguments, first is the effort made by taxpayers to reduce costs so that they can still compete in the market. This is in line with Shleifer (2004). Second, tax avoidance is only a result of the company's strategy to remain competitive in the market by lowering prices, which implies lower corporate profits and lower taxes which are often seen as tax avoidance.

Further, perceived tax fairness also significantly affects tax compliance. When taxpayers perceive tax systems fair, neutral, and reliable, they are more likely to exhibit greater tax compliance behavior. Similarly, when taxes paid by the formal sector are commensurate with fairness received by formal taxpayers both distributive, procedural, and retributive, the formal sector tends to comply with tax regulations. Fair, clear, and consistent tax systems will then enhance tax compliance. The findings are supported by Akinboade (2015) and not in line with Zhiyong \& Qingyang (2007) and Saad (2012).

This study also shows that the interaction between the formal sector's perception of market competition and tax fairness empirically affects tax compliance. The interaction between the formal sector's low perceived market competition and high perceived tax fairness results in the highest tax compliance. The results imply that these two factors are not substitutive in the sense that high perceived market competition and high perceived tax fairness still do not lead to greater tax compliance. In a similar vein, low perceived tax fairness and low perceived market competition do not enhance tax compliance. Thus, governments need to reduce the formal sector's perception of market competition and simultaneously to increase the formal sector's perception of tax fairness to enhance tax compliance significantly. Only focusing on a single variable will not enhance tax compliance significantly.

The results are in line with the fiscal psychology theory that argues that taxpayers are less motivated to pay taxes because they do not obtain tangible benefits of paying taxes, both economic and economical. The formal sector will perceive the benefits of paying taxes when they consider market competition with the informal sector low and the fairness of tax systems high. When perceived market competition is low and perceived tax fairness is high, the formal sector's innovation and tax costs will be relatively equal to informal firms' and formal firms can compete with the informal sector in terms of operating costs and prices. Thus, the formal sector will not change their behavior to avoid taxes and even will enhance their tax compliance because current conditions confirm their expectations.

The study also suggests that firm size and firm age as the control variables significantly affect tax compliance. Smaller firms tend to comply more with tax regulations than larger firms. Also, firms operating longer are less tax-compliant than newly operating firms. We argue that firms that operate longer are more skillful and experienced to manage their tax-related financial matters and inline with Mariusz (2016).

\section{CONCLUSION}

Formal firms' tax compliance is a challenging issue for developing countries. In this respect, unfavorable market competition is likely to motivate formal firms to exhibit tax non-compliant behavior. Formal firms will find it difficult to compete with informal firms because the cost advantage of the informal sector enables informal firms to sell their products at lower prices. For example, it is indicated that informal firms tend to imitate formal firms' products. Thus, informal firms arguably manage to eliminate research and development costs. Besides, they often receive favored treatments from their governments. Consequently, formal firms will arguably reduce operating costs such as by avoiding taxes to reduce their 
prices. Further, firms' tax compliance is also related to tax fairness. Tax systems that are considered unfair will lead taxpayers to perceive their governments to be unfair, partial, and poor. Eventually, firms will have less trust to exhibit tax compliant behavior.

This study aims to test the effects of market competition between formal firms and informal firms and perceived fairness with tax compliance. The results demonstrate that the formal sector's perception of the market competition between the formal and informal sectors and on tax fairness affect tax compliance. Further, the interaction between market competition and tax fairness also affects firms' tax compliance level. When perceived market competition is low and tax fairness is high, formal firms will exhibit greater tax compliance. On the contrary, when perceived market competition is high and tax fairness is low, tax compliance will be lower. In addition, this study also shows that in situations of high perception of tax fairness, although also faced with high informal competition, will still create high tax compliance compared to if faced with situations of low perception of tax fairness with low informal competition. This shows that the perception of tax fairness is crucial for formal firms to comply with their tax obligations.

Our findings practically imply that governments should consider these two factors to increase the formal sector's tax compliance. Specifically, governments are expected to reduce market competition between formal and informal firms and to enhance the fairness of their tax systems to facilitate fair competition between these firms. For example, governments can implement laws to effectively protect formal firms' patent rights on their product innovation from infringements.

A limitation of this study is that it relies on a more general perspective of tax fairness. Also, as a study that uses cross-country data with various tax compliance, this study does not focus on country-level variations such as whether countries exhibit tax conformity and aggressiveness culture. Thus, we advise future studies to incorporate the role of tax-related, country-level culture in their analysis.

\section{REFERENCES}

Akinboade, O. A. (2015). Correlates of tax Compliance of small and medium-size businesses in Cameroon. Managing Global Transitions, 13(4), 389-413.

Alm, James, Sanchez, I., \& Juan, A. de. (1995). Economic and non- economic factors in tax compliance. Kyklos, 48(1), 3-18.

Alon, A., \& Hageman, A. M. (2013). The impact of corruption on firm tax compliance in transition economies: Whom do you trust? Journal of Business Ethics, 116(3), 479-494. doi: https://doi.org/10.1007/s10551-012-1457-5

Andreoni, J., Erard, B., \& Feinstein., J. S. (1998). Tax compliance. Journal of Economic Psychology, 27, 224-246.

Barbuta-Misu, N. (2011). A review of factors for tax compliance. "Dunarea de Jos" University of Galati Fascicle I. Economics and Applied Informatics, 1(1), 69-76.

Baum, A., Gupta, S., Kimani, E., \& Tapsoba, S. J. (2017). Corruption, taxes and compliance. EJournal of Tax Research, 15(2), 190-216.

Benjamin, N., Beegle, K., \& Santini, F. R. M. (2014). Informal economy and the World Bank. Policy Research Working Paper, 6888(May), 1-36. doi: https://doi.org/10.1097/ICO.0b013e3181eadd0f

Bertinelli, L., Bourgain, A., \& Leon, F. (2018). Corruption and tax compliance: evidence from small retailers in Bamako, Mali. Discussion Paper Luxembourg: Universite Du Luxembourg.

Blaufus, K., Bob, J., Hundsdoerfer, J., Sielaff, C., Kiesewetter, D., \& Weimann, J. (2015). Perception of income tax rates: evidence from Germany. European Journal of Law and Economics, 40(3), 457-478. doi: https://doi.org/10.1007/s10657-013-9389-9

Bruton, G. D., Ireland, R. D., \& Ketchen, D. J. (2012). Toward a research agenda on the informal economy. Academy of Management Perspectives, 26(3), 1-11. doi: https://doi.org/10.5465/amp.2012.0079 
Chen, S., Chen, X., Cheng, Q., \& Shevlin, T. (2010). Are family firms more tax aggressive than non-family firms?. Journal of Financial Economics, 95 (1), 41-61. doi: https://doi.org/10.1016/j.jfineco.2009.02.003

Chung, J. and Trivedi, U. V (2003). The effect of friendly persuasion and gender on tax compliance behaviour, Journal of Business Ethics, 47, 133 - 145.

Cropanzano, R., Rupp, D.E., Mohler, CJ., \& Schminke, M. (2001). Three roads to organizational justice. Personnel and Human Resources Management, 20, 1 - 113

Cyan, M. R., Koumpias, A. M., \& Martinez-Vazquez, J. (2016). The determinants of tax morale in Pakistan. Journal of Asian Economics, 47, 23-34.

Damayanti, T.W., Nastiti, P.K.Y., \& Supramono, S. (2020). Does tax amnesty influence intention to comply?: If students are taxpayers already. Business Management and Education, 18(1), 1-13, doi: 10.3846/bme.2020.10292

Dijke, V., \& Verboon, P. (2010). Trust in authorities as a boundary condition to procedural fairness effects on tax compliance. Journal of Economic Psychology, 31, 80-91, doi: https://doi.org/10.1016/j.joep.2009.10.005

Dobrovič, J., Rajnoha, R., Voznakova, I., \& Pártlová, P. (2019). Action plan on sustainability of fight against tax fraud and tax evasion: EU countries comparison. Journal of International Studies, 12(4), 272-285. doi:10.14254/2071-8330.2019/12-4/17

Dolores, R., Alarcon, G., \& Garre, M. E. (2010). Tax morale in Spain: A study into some of its principal determinants. Journal of Economic Issues, 44(4), 855-876. doi: https://doi.org/10.2753/jei00213624440401

Feld, L., \& Frey, B. 2002. Trust breeds trust: How taxpayer are treated. Economics of Governance 3, 87-99.

Feld, L. P., \& Frey, B. S. (2007). Tax compliance as the result of a psychological tax contract: the role of incentives and responsive regulation. Law \& Policy, 29(1), 102-120.

Gberegbe, F. B., Idornigie, G. A., \& Nkanbia-Davies, L. O. (2015). Perception of tax fairness and personal income tax compliance in Ken Saro-Wiwa Polytechnic, Bori. IOSR Joumal of Economics and Finance, 6(6), 2321-5933. doi: https://doi.org/10.9790/5933-06610111

Gokalp, O. N., Lee, S. H., \& Peng, M. W. (2017). Competition and corporate tax evasion: An institutionbased view. Journal of World Business, 52(2), 258-269. doi: https://doi.org/10.1016/j.jwb.2016.12.006

Han, J. (2008) The business strategy of Mc Donald's, International Journal of Business and Management, 3 (11), $72-74$

Hanlon, M., and Heitzman, S. (2010).A review of tax research. Journal of Accounting and Economics, 50(2-3),127178. doi: https://doi.org/10.1016/j. jacceco.2010.09.002

Hasseldine, D. J., \& Bebbington, K. J. (1991). Blending economic deterrence and fiscal psychology models in the design of responses to tax evasion: The New Zealand experience. Journal of Economic Psychology, 12(2), 299-324. https:// doi.org/10.1016/0167-4870(91)90018-O

Hartner, M., Rechberger, S., Kirchler, E., \& Schabmann, A. (2008). Procedural fairness and tax compliance. Economic Analysis Policy, 38(1), 137-152.

Heredia, J., Flores, A., Geldes, C., \& Heredia, W. (2017). Effects of informal competition on innovation performance: The case of Pacific Alliance. Journal of Technology Management \& Innovation, 12(4), 22-28.

Hofmann, E., Hoelzl, E, and Kirchler, E (2008). Preconditions of voluntary tax compliance: knowledge and evaluation of taxation, norms, fairness and motivation to cooperate. Journal of Psychology, 216(4), 209 217.

Heartrepreneur (2017). Gain competitive advantage with low-cost leadership strategy, Retrieved May 2019 from https://heartrepreneur.com/gain-competitive-advantage-low-cost-leadership-strategy/

Hyun, J. K. (2005). Tax compliances in Korea and Japan: why are they different? Paper presented at Policy Research Institute. Ministry of Finance, Japan. 
James, S., Murphy, K., \& Reinhart, M. 2005. Taxpayer beliefs and views: two new surveys. Australian Tax Forum, 20, 157-188.

Jaya, A., Ratnawati, T., \& Sardjono, S. (2017). Analysis of effect of knowledge and service quality, accessibility of information, awareness and behavior of taxpayers and impact on satisfaction and compliance with taxpayers of land and buildings in The City Batam Island Riau Province. International Journal of Business and Management Invention, 6(8), 73-83.

Karlinger, L. (2009). The underground economy in the late 1990s: evading taxes, or evading competition? World Development, 37(10), 1600-1611. https://doi.org/10.1016/j.worlddev.2009.03.001

Karlinger, L. (2014). The "Dark Side" of deregulation: how competition affects the size of the shadow economy. Journal of Public Economic Theory, 16(2), 293-321. doi: 10.1111/jpet.12053

Keen, M. (2012). Taxation and development-again. IMF Working Papers, 12(220), 1-30. doi: https://doi.org/10.5089/9781475510294.001

Khuong, N. V, Ha, N. T. T., Minh, M.T.H., \& Thu, P. A. (2019). Does corporate tax avoidance explain cash holdings? The case of Vietnam. Economics and Sociology, 12(2), 79-93. doi:10.14254/2071789X.2019/12-2/5

Kim., C.K. (2002). Does fairness matter in tax reporting behavior?. Journal of Economic Psychology, 23, 771785.

Kim, S., Kim, H., Her, M., \& Kim, H. (2008). Does political intention affect tax evasion? Journal of Policy Modeling, 30(3), 401-415.

Kim, J., Y. Li, and L. Zhang. (2011). Corporate tax avoidance and stock price crash risk: Firm-level analysis. Journal of Financial Economics, 100 (3), 639-662. https://doi.org/10.1016/j.jfineco.2010.07.007

Kirchler, E., Muehlbacher, S., Kastlunger, B., \& Wahl, I. (2007). Why paying taxes? A review of tax compliance decisions. International Center for Public Policy Working Paper Series, at AYSPS, GSU paper 0730, International Center for Public Policy, Andrew Young School of Policy Studies, Georgia State University.

Kogler, C., Batrancea, L., Nichita, A., Pantya, J., Belianin, A., \& Kirchler, E. (2013). Trust and power as determinants of tax compliance: Testing the assumptions of the slippery slope framework in Austria, Hungary, Romania and Russia. Journal of Economic Psychology, 34, 169-180. doi: https://doi.org/10.1016/j.joep.2012.09.010

Kogler, C., Muehlbacher, S., \& Kirchler, E. (2013). Trust, power, and tax compliance: testing the "Slippery Slope Framework" among self-employed taxpayers. WU International Taxation Research Paper Series. https://doi.org/10.2139/ssrn.2294886

Kostritsa, M., \& Sittler, I. (2017). The impact of social norms, trust, and fairness on voluntary tax compliance in Austria. Management, 12(4), 333-354. doi: 10.26493/1854-4231.12.333-353

Kotler, P. (2000). Marketing Management, Millenium Edition (Tenth Edit). Prentice-Hall, Inc.

Kubick, T.R, Lynch, D.P., Mayberry, M.A., \& Omer, T.C.(2015). Product Market Power and Tax Avoidance: Market Leaders, Mimicking Strategies, and Stock Returns. The Accounting Review, 90(2), 675-702,doi: 0.2308/accr-50883

Kubicová, J., \& Záhumenská, M. (2017). Survey Research on Whether Taxes Affect Decisions of Slovak Managers on Cross-border Financial Restructuring Operations. Journal of International Studies, 10(2), 74 89. doi:10.14254/2071 -8330.2017/10-2/5

Loo, E. C., Evans, C., \& McKerchar, M. (2010). Challenges in understanding compliance behavior of taxpayers in Malaysia. Asian Journal of Business and Accounting, 3(2), 145-161. doi: https://doi.org/10.2139/ssrn.2128378

Leder, S., Mannetti, L., Hoelzl, E and Kirchler, E (2010). Regulatory fit effects on perceived fiscal exchange and tax compliance, The Journal of Socio-Economics, 39, 271277.

Mangoting, Y., Sukoharsono, E. G., Rosidi, \& Nurkholis. (2015). Developing a model of tax compliance 
from social contract perspective: mitigating the tax evasion. Procedia - Social and Behavioral Sciences, 211, 966-971. doi: https://doi.org/10.1016/j.sbspro.2015.11.128

Mas'ud, A., Manaf, N. A. A., \& Saad, N. (2019). Trust and power as predictors to tax compliance: Global evidence. Economics and Sociology, 12(2), 192-204. doi:10.14254/2071-789X.2019/12-2/11

Mathias, B. D., Lux, S., Russell Crook, T., Autry, C., \& Zaretzki, R. (2015). Competing against the unknown: the impact of enabling and constraining institutions on the informal economy. Journal of Business Ethics, 127(2), 251-264. doi: https://doi.org/10.1007/s10551-013-2030-6

Mariusz, N. (2016). Tax planning for small and medium enterprises (SMEs). Annals of Marketing Management \& Economics, 2 (1), 91-98.

McCann, B. T., \& Bahl, M. (2016). The influence of competition from informal firms on new product development. Strategic Management Journal, 38(7), 1519-1535. doi: https://doi.org/10.1002/smj.2585

Mei-Tan, L. \& Chin-Fatt, C. (2000), The impact of tax knowledge on the perceptions of tax fairness and attitudes towards compliance, Asian Review of Accounting, 8(1), 4458. https://doi.org/10.1108/eb060720

Modugu, K. P., \& Anyaduba, J. O. (2014). Impact of tax audit on compliance in Nigeria. International Journal of Business and Social Science, 5(9), 207-215.

Murphy, K. (2007). Procedural justice and the regulation of tax compliance behavior : the moderating role of personal norms, International Studies Program Working Paper 07-31 December 2007

Mustapha, B., \& Obid, S. N. B. S. (2015). Tax service quality: the mediating effect of perceived ease of use of the online tax system. Procedia - Social and Behavioral Sciences, 172, 2-9. doi: https://doi.org/10.1016/j.sbspro.2015.01.328

Nichter, S., \& Goldmark, L. (2009). Small firm growth in developing countries. World Development, 37(9), 1453-1464. doi: https://doi.org/10.1016/j.worlddev.2009.01.013

Oberholzer, R. and Stack, M. E (2014). Perceptions of taxation: A comparative study of different population groups in South Africa, Public Relations Review, 40, $226-239$. https://doi.org/10.1016/j.pubrev.2013.11.010

OECD. (2014). Measures of Tax Compliance Outcomes: A Practical Guide. OECD Publishing. https://doi.org/10.1787/9789264223233-en

Olaoye, C. O., Ayeni-Agbaje, A. R., \& Alaran-Ajewole, A. P. (2017). Tax information, administration and knowledge on tax payers' compliance of block moulding firms in Ekiti State. Journal of Finance and Accounting, 5(4), 131. doi: https://doi.org/10.11648/j.jfa.20170504.12

Palil, M. R., Akir, M. R. M., \& Ahmad, W. F. B. W. (2013). The perception of tax payers on tax knowledge and tax education with level of tax compliance : a study the influences of religiosity. ASEAN Journal of Economics, Management and Accounting, 1(1), 118-129.

Poppelwell, E., Kelly, G., \& Wang, X. (2012). Intervening to reduce risk: identifying sanction thresholds among SME tax debtors. EJournal of Tax Research, 10(2), 403-435.

Porter, Michael, Competitive advantage, The Free Press, NY, 1985.

Rego, S. O., and R. Wilson. (2012). Equity risk incentives and corporate tax aggressiveness. Journal of Accounting Research, 50 (3): 775-810. https://doi.org/10.1111/j.1475-679X.2012.00438.x

Richardson, G. (2008) The relationship between culture and tax evasion across countries: additional evidence and extensions. Journal of International Accounting, Auditing and Taxation, 17(2), 67-78

Rosid, A., Evans, C., \& Tran-Nam, B. (2018). Tax non-compliance and perceptions of corruption: policy implications for developing countries. Bulletin of Indonesian Economic Studies, 54(1), 25-60. doi: https://doi.org/10.1080/00074918.2017.1364349

Rudolph, T. J. (2009). Political trust, ideology, and public support for tax cuts. Public Opinion Quarterly, 73(1), 144-158. doi: https://doi.org/10.1093/poq/nfp012 
Saad, N. (2012). Perceptions of tax fairness and tax compliance behavior: A comparative study. Jurnal Pengurusan, 3, 89 - 100

Sapiei, N. S., Kasipillai, J., \& Eze, U. C. (2014). Determinants of tax compliance behavior of corporate taxpayers in Malaysia. EJournal of Tax Research, 12(2), 383-409. doi: https://doi.org/10.2989/1814232X.2016.1145597

Savitri, E., \& Musfialdy. (2016). The effect of taxpayer awareness, tax socialization, tax penalties, compliance cost at taxpayer compliance with service quality as mediating variable. Procedia - Social and Behavioral Sciences, 219, 682-687. doi: https://doi.org/10.1016/j.sbspro.2016.05.051

Schmolders, G. (1959). Fiscal psychology: A new branch of public finance. National Tax Journal, 12(4), 340345.

Schmidt, K. (1997). Managerial incentives and product market competition. Review of Economic Studies, 64 (2) 191-213.

Singh, V., \& Bhupalan, R. (2001). The Malaysian self-assessment system of taxation: issues and challenges. Tax National, 1 (3), 12-17.

Shin, I.,\& Park, S. (2019). The relation between product market competition and corporate tax avoidance: evidence from Korea. Investment Management and Financial Innovations, 16 (2), 313-325. doi: http://dx.doi.org/10.21511/imfi.16(2).2019.26

Stamatopoulos, I., Hadjidema, S., \& Eleftheriou, K. (2017). Corporate income tax compliance costs and their determinants: Evidence from greece. Advances in Taxation, 24, 233-270. doi: https://doi.org/10.1108/S1058-749720170000024006

Swenson, C. (1999). Increasing stock market value by reducing effective tax rates, Tax Notes, 83, 1503-1505.

Tanwar, R. (2013). Porter's generic competitive strategies, IOSR Journal of Business and Management, 15 (1), $11-17$

Tahar, A., \& Rachman, A. K. (2014). Pengaruh faktor internal dan faktor eksternal terhadap kepatuhan wajib pajak. Akuntansi UMY, 15(1), 1-12.

Tan, L. M. \& Chin-Fatt, C. 2000. The impact of tax knowledge on the perceptions of tax fairness and attitude towards compliance. Asian Review of Accounting, 8(1), 44-58.

Turner, J. C. 2005. Explaining the nature of power: A three-process theory. European Journal of Social Psychology, 35(1), 1-22.

Tyler, T. R (2006). Why people obey the law. Princeton: Princeton University Press.

Wang (2019). Product market competition and efficiency of corporate tax management. Asian Review of Accounting, 27 (2), 247-272. doi:10.1108/ARA-07-2018-013

Wenzel, M. (2003).Tax compliance and the psychology of justice : mapping the field. United Kingdom: Ashgate Publishing Ltd. Aldershot: Ashgate

Williams, C. C., \& Nadin, S.J. (2015). Tackling entrepreneurship in the informal economy: evaluating the policy options. Journal of Entrepreneurship and Public Policy, 1(2), 111-124 doi:http://dx.doi.org/10.1108/20452101211261408 